papillary muscles. Another was the hole type, in which there was a simple large hole in a cusp. Miyamura and associates ${ }^{2}$ reported a case of central-type anomaly, in which the anterior leaflet was divided completely with a well-developed papillary muscle and chordae tendineae. The present case was similar to the case of Miyamura and associates ${ }^{2}$ : the tricuspid valve had a completely independent accessory leaflet with well-developed apparatus structures.

Procedures for correction of the Ebstein anomaly that restore the tricuspid valve to near normal anatomic and physiologic function have been reported, ${ }^{3-5}$ other than monocuspid valve reconstruction using an enlarged anterior leaflet. Valve reparability is reported to depend on the valve leaflet location and morphologic features. ${ }^{1}$ Da Silva and colleagues ${ }^{4}$ reported a surgical technique called "cone reconstruction," in which the anterior and posterior tricuspid valve leaflets mobilized from the right ventricle were rotated clockwise, creating a cone, the base of which was sutured to the true tricuspid valve annulus level, and its free edge was sutured to the septal border of the anterior leaflet. Wu and associates ${ }^{5}$ reported anatomic repair using posterior and sep- tal leaflets, a "new leaflet" being made from the posterior and septal leaflets or a piece of fresh autologous pericardium depending on the size of the septal and posterior leaflets. Our surgical technique was the modification of the concept of creating "new septal leaflet" repairs using the accessory leaflet. To our knowledge this is the first case reported in the literature of a patient with Ebstein anomaly associated with double orifice of the tricuspid valve who underwent successful surgical repair.

\section{References}

1. Sánchez Carlos A, Rábago P, Sokolowski M. Duplication of the tricuspid valve. $\mathrm{Br}$ Heart J. 1967;29:943-6.

2. Miyamura H, Matsukawa T, Maruyama Y, Nakazawa S, Eguchi S. Duplication of the tricuspid valve with Ebstein anomaly. Jpn Circ J. 1984;48:336-8.

3. Brown ML, Dearani JA, Danielson GK, Cetta F, Connolly HM, Warnes CA, et al Mayo Clinic Congenital Heart Center. The outcomes of operations for 539 patients with Ebstein anomaly. J Thorac Cardiovasc Surg. 2008;135:1120-36.

4. da Silva JP, Baumgratz JF, da Fonseca L, Franchi SM, Lopes LM, Tavares GMP, et al. The cone reconstruction of the tricuspid valve in Ebstein's anomaly. The operation: early and midterm results. J Thorac Cardiovasc Surg. 2007;133:215-23.

5. Wu Q, Huang Z, Pan G, Wang L, Li L, Xue H. Early and midterm results in anatomic repair of Ebstein anomaly. J Thorac Cardiovasc Surg. 2007;134: $1438-42$.

\title{
Right ventricular approach for securing the aortic homograft to the interventricular septum in bacterial endocarditis
}

\author{
Morteza Tavakkoli Hosseini, MD, Antonios Kourliouros, MRCS, and Mazin Sarsam, FRCS, London, \\ United Kingdom
}

We present here a case of aortic homograft implantation for aortic root abscess with involvement of the interventricular septum. Because of the extensive involvement of the septum, the conventional approach for securing the homograft to the interventricular septum failed, and subsequently the homograft was fixed to the septum by direct approach through the right ventricle.

\section{CLINICAL SUMMARY}

A 27-year-old man with methicillin-resistant Staphylococcus aureus septicemia resulting from dialysis line infec-

\footnotetext{
From the Department of Cardiothoracic Surgery, St Georges Hospital, London, United Kingdom.

Disclosures: None.

Received for publication May 22, 2009; accepted for publication Sept 8, 2009; available ahead of print Nov 12, 2009.

Address for reprints: Mazin Sarsam, FRCS, Department of Cardiothoracic Surgery, St Georges Hospital, BlackShaw Rd, London SW17 0QT, United Kingdom (E-mail: mazin.sarsam@stgeorges.nhs.uk).

J Thorac Cardiovasc Surg 2010;139:e133-4

$0022-5223 / \$ 36.00$

Copyright (c) 2010 by The American Association for Thoracic Surgery

doi:10.1016/j.jtcvs.2009.09.020
}

tion had the symptoms of pulmonary edema and shortness of breath. Echocardiography showed $4+$ aortic regurgitation with complete destruction of the aortic valve, aortic root abscess extending to the interventricular septum along the right coronary sinus of Valsalva, mild mitral regurgitation with clear mitral valve leaflets, an area of localized infection on the tricuspid valve between the commissure of the septal and posterior leaflets, and a $4 \times 4-\mathrm{cm}$ mass in the right atrium near the inferior vena cava. The patient's medical history included sickle cell trait, ulcerative colitis, hemolytic uremic syndrome, and resultant renal failure.

The patient was taken to the operating room for emergency aortic root replacement and removal of the right atrial mass. After median sternotomy, aortobicaval cardiopulmonary bypass was established. No significant abnormalities were noticed at the surface of the heart. The right atrium was opened, and the friable mass along the inferior vena cava was removed. An area of localized infection was found on the tricuspid valve between the posterior and septal leaflets. It was débrided and washed with vancomycin with preservation of the tricuspid valve. The ascending aorta was 
transected, and the echocardiographic findings were confirmed. The aortic valve was excised, and the right and left coronary buttons were harvested. The infected tissue and the abscess at the top of the muscular part of the interventricular septum were débrided completely (partial-thickness débridement of the septum). Implantation of a 21-mm aortic homograft was attempted with interrupted 4-0 braided polyethylene terephthalate sutures (TI • CRON; Covidien plc, Loughlinstown, Ireland). Securing the sutures to the interventricular septum by the conventional approach proved to be impossible because of the remaining thin, fragile interventricular septum. Placement of the sutures into the healthy part of the inter-ventricular septum was not attempted, because the healthy part of the septum was too low and fixing the homograft to this part would result in anatomic distortion of the homograft. Longitudinal right ventriculotomy was performed, as described for the Konno-Rastan technique. ${ }^{1,2}$ Interrupted 4-0 TI $\bullet$ CRON sutures (reinforced with bovine pericardial pledgets) were placed into the interventricular septum from the right ventricular side, emerging into the left ventricle. The homograft was then fixed in the normal anatomic position (Figure 1). The coronary buttons were anastomosed to the aortic homograft, and the right ventriculotomy was closed without a patch. Distal homograft anastomosis was performed. The right atriotomy was closed, and the patient was weaned from cardiopulmonary bypass with some inotropic support. Postoperative echocardiography confirmed a well-seated and functioning aortic homograft. The patient had a good postoperative recovery and was discharged home on day 37 once the antibiotic course was completed. Postoperative electrocardiography showed right bundle branch block, which did not require any intervention. The histopathologic review of the aortic valve confirmed bacterial endocarditis. The débrided interventricular septum was reported to be acutely inflamed, and the right atrial mass proved to be thrombotic tissue with numerous gram-positive cocci.

\section{DISCUSSION}

The Konno-Rastan procedure, which was originally described in 1975, is used to tackle the problem of subaortic stenosis through a right ventricular approach. The procedure consists of a longitudinal incision in the aorta placed in the midportion of both coronary ostia, a vertical incision in the outflow tract of the right ventricle to join the septal incision, prosthetic aortic valve replacement, and patch reconstruc-

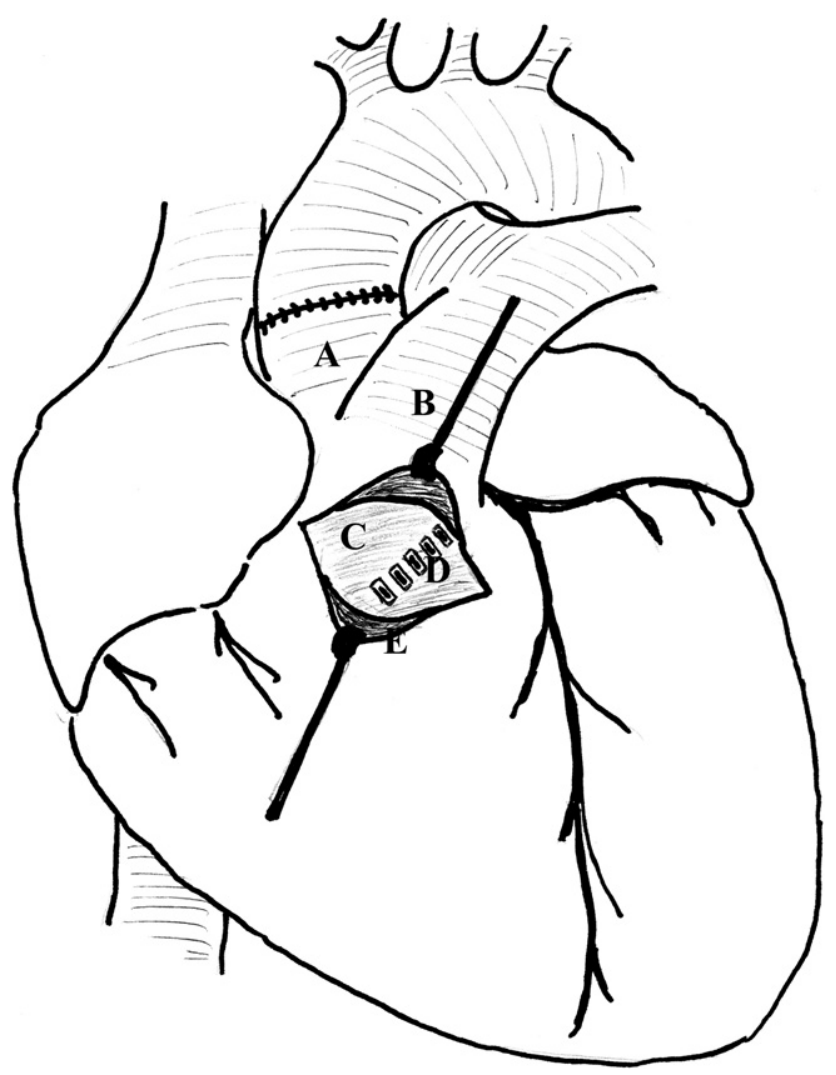

FIGURE 1. Anterior view of heart with aortic homograft $(A)$ secured with pledgeted sutures $(D)$ placed through interventricular septum $(C)$ by way of longitudinal right ventriculotomy $(E)$. $B$, Main pulmonary artery.

tion of the outflow tracts of both ventricles by means of 2 layers of a fusiform Dacron polyester fabric patch. ${ }^{1,2}$

In the scenario presented in our case report, the direct right ventricular approach as described in the Konno-Rastan procedure proved to be of great value. We took advantage of the ventricular incision of this technique to approach the interventricular septum from the right ventricular side and secure the aortic homograft to the septum with confidence.

\section{References}

1. Rastan H, Koncz J. [Plastic enlargement of the left ventricular outflow tract. A new operative method]. Thoraxchir Vask Chir. 1975;23:169-75. German.

2. Konno S, Imai Y, Iida Y, Nakajima M, Tatsuno K. A new method for prosthetic valve replacement in congenital aortic stenosis associated with hypoplasia of the aortic valve ring. J Thorac Cardiovasc Surg. 1975;70:909-17. 